JC)
unnal publiuho is licensed under a Creative Commons Attribution 4.0 International License, which permits
unrestricted use, distribution, and reproduction in any medium, provided the original work is properly cited.

\title{
KEBIJAKAN PENGEMBANGAN INFRASTRUKTUR TRANSPORTASI LAUT PADA DINAS PERHUBUNGAN KABUPATEN MUNA BARAT Sartono' \\ ${ }^{1}$ Fakultas IImu Sosial dan IImu Politik Universitas Halu Oleo sartonos1969@gmail.com
}

\begin{abstract}
This study aims to determine the policies carried out by the transportation agency in an effort to develop marine transportation infrastructure and the benefist that can be obtained in the development of the marine transportation infrastructure.

The informant in this study concisted of head of the department transportation districts Muna Barat, secretary department transportation districts Muna Barat, and head of development and safety department transportation districts Muna Barat.

The results of this study indicate that policy department transportation districtsMuna Barat in development infrastructure water transportation seen from three policies. Firts, infrastructure investment is considered good seen from the collaborationdone with several parties which has invest several ships that have been operated in several ports which exists ini Muna Barat. Second, development infrastructure port assessed already enough good seen from development docks and port which exists in islands small in region districts Muna Barat. Third, expansion capacity port assessed already good seen from additions long from port people Latawe and port people Pajala and additions large at the port Tondasi. Benefist development infrastructure port covers economic growth, job creation, and development economic national and regional. If seen from the fact that is there can be it is said that as is development port or infrastructure water trasportation then very have a positive impact in economic growth, job creation, and development economic national and regional because the port is an asset regional and country very important in support smooth turnaround the wheel economic remembering indonesia is archipelago state.
\end{abstract}

Keywords: Infrastructure Development; Policy; Sea Transportation 
Vol.2 No.2. May-July 2019. pp.84-98. Copyright@2019 Journal PUBLICUHO Faculty of Social and Political Sciences Halu Oleo University, Kendari, Southeast Sulawesi, Indonesia. e-ISSN: 2621-1351.Open Access at:

http://ojs.uho.ac.id/index.php/PUBLICUHO

Jounal publiuho is licensed under a Creative Commons Attribution 4.0 International License, which permits unrestricted use, distribution, and reproduction in any medium, provided the original work is properly cited.

\section{PENDAHULUAN}

Pengembangan transportasi harus di dasarkan pada pengembangan yang berkelanjutan (sustainability), yaitu melihat jauh kedepan, berdasarkan perencanaan jangka panjang yang komprehensif dan berwawasan lingkungan. Perencanaan jangka pendek harus di dasarkan pada pandangan jangka panjang sehigga tidak terjadi perencanaan bongkar pasang terutama yang berhubungan dengan penerapan kebijakan pemerintah di setiap pergantian kepemimpinan (Adisasmita, 2011).

Pembangunan infrastruktur suatu wilayah dapat memberikan pengaruh pada peningkatan akses masyarakat terhadap sumber daya sehingga meningkatkan akses produktivitas sumber daya yang pada akhirnya mendorong pertumbuhan ekonomi.(Sudaryadi, 2007). Infrastruktur atau sarana dan prasarana memiliki keterkaitan yang sangat kuat dengan dengan kesejahteraan sosial dan kualitas lingkungan juga terhadap proses pertumbuhan ekonomi suatu wilayah atau region. Hal tersebut dapat ditunjukkan dengan indikasi bahwa wilayah yang memiliki kelengkapan sistem infrastruktur lebih baik biasanya mempunyai tingkat kesejahteraa sosial dan kualitas lingkungan serta pertumbuhan ekonomi yang lebih baik pula (Departemen Pekerjaan Umum, 2006). Pembangunan infrastruktur pelabuhan membutuhkan biaya yang besar, keberhasilan ataupun kegagalan dari proyek tersebut akan memiliki implikasi jangka panjang (Musso et. al., 2006).

Kabupaten Muna Barat sebagai daerah otonomi baru yang memiliki potensi kelautan yang cukup menunjang terlebih lagi sektor laut Muna Barat berbatasan langsung dan terhubung dengan beberapa kabupaten/kota lainnya di Sulawesi Tenggara.Muna Barat memiliki letak yang strategis dan sebagian besar wilayahnya merupakan lautan sehingga sangat di perlukan dan di butuhkan kinerja Dinas Perhubungan dalam mengimplementasikan kebijakan pengembangan transportasi laut dalam hal ini pelabuhan.

Transportasi laut memegang peranan penting dalam kelancaran perdagangan karena memiliki nilai ekonomis yang tinggi antara lain daya angkut banyak, dan biaya relatif murah. Guna menunjang perdagangan dan lalu-lintas muatan, pelabuhan diciptakan sebagai titik simpul perpindahan muatan barang dimana kapal dapat berlabuh, bersandar, melakukan bongkar muat barang dan penerusan ke daerah lainnya.

Pelabuhan merupakan sarana yang sangat penting terutama untuk transportasi laut, dengan adanya transportasi ini jarak tempuh yang di butuhkan akan lebih cepat terutama bagi perkembangan ekonomi suatu daerah di mana pusat produksi barang konsumen bisa di pasarkan dengan cepat dan lancar. Selain itu juga pada bidang ekonomi, pelabuhan membawa dampak positif bagi perkembangan suatu daerah yang terisolir terutama daerah perairan dimana aksesibilitas melalui darat sulit di lakukan.

Melihat aktivitas kepelabuhanan yang terus meningkat, maka hal penting dilakukan untuk meningkatkan pengelolaan dan kinerja dari pelayanan pelabuhan dengan menyiapkan infrastruktur, sarana dan prasarana yang memadai untuk dapat menunjang kelancaran operasional pelayanan di Pelabuhan Tondasi.Berdasarkan uraian diatas, maka perlu dilakukan penelitian untuk menganalisis kebijakan darai pemerintah dalam merumuskan strategi pengembangan dalam mendukung pembangunan.

Pembangunan dan Pengembangan beberapa Pelabuhan yang ada di Kabupaten Muna Barat menunjukan kesungguhan pemerintah Kabupaten Muna pada saat itu dalam mengoptimalkan bembangunan di bidang transportasi laut dan pelayanan kepada masyarakat.Pelabuhan tersebut di bangun sebelum pemekaran Kabupaten Muna Barat yang bertempat dibeberapa Kecamatan yang dulu masih merupakan bagian dari Kabupaten Muna dimana pelabuhan ini di bangun pada masa pemerintahan Ridwan BAE. Namun pada saat itu belum ada perhatian lebih dari pemerintah Daerah dalam 
Vol.2 No.2. May-July 2019. pp.84-98. Copyright@2019 Journal PUBLICUHO Faculty of Social and Political Sciences Halu Oleo University, Kendari, Southeast Sulawesi, Indonesia. e-ISSN: 2621-1351. Open Access at:

http://ojs.uho.ac.id/index.php/PUBLICUHO

Jounal publiuho is licensed under a Creative Commons Attribution 4.0 International License, which permits unrestricted use, distribution, and reproduction in any medium, provided the original work is properly cited.

pengembangan infrastruktur pelabuhan.Sehingga infrastruktur yang ada dan kegiatan kepelabuhanan belum maksimal.

Beberapa tahun kemudian, Muna Barat telah mekar menjadi sebuah Daerah Otonomi baru dan memberikan dampak yang positif dalam hal pembangunan terutama infrastuktur transportasi.Di harapkan ada upaya pengembangan infrastruktur pelabuhan untuk menunjang kembali berjalannya kegiatan pelayaran. Pemerintah Daerah dan Dinas perhubungan Kabupaten Muna Barat telah melakukan kerja sama dengan salah satu perusahaan Swasta untuk mengoperasikan kapal cepat atau biasa disebut Speed dengan rute perjalanan Pajala-Kasipute. Keberadaan pelabuhan diharapkan memberikan dampak pada pembangunan ekonomi di sekitar wilyah pelabuhan, sehingga keberhasilan pembangunan pelabuhan tidak hanya memberikan keuntungan bagi para investor tetapi juga pada pemerintah dan masyarakat melalui penyebaran kawasan perekonomian di sekitar pelabuhan (Ho dan Ho, 2006).

Berdasarkan uraian di atas, maka penulis tertarik untuk melakukan penelitian dengan judul: "Analisis Kebijakan Pembangunan Pelabuhan dalam Pengembangan Infrastruktur Transportasi Laut pada Dinas Perhubungan Kabupaten Muna Barat.

\section{TINJAUAN PUSTAKA}

\section{A. Konsep Analisis Kebijakan}

Kebijakan Secara etimologi, istilah kebijakan berasal dari Bahasa Inggris "policy".Pendapat Anderson yang dikutip oleh Wahab, merumuskan kebijaksanaan sebagai perilaku dari sejumlah aktor (pejabat, kelompok, instansi pemerintah) atau serangkaian aktor dalam suatu bidang kegiatan tertentu. (Anderson dalam Wahab, 2008:2). Oleh karena itu, kebijaksanaan menurut Anderson merupakan langkah tindakan yang sengaja dilakukan oleh aktor yang berkenaan dengan adanya masalah yang sedang di hadapi.Kebijakan publik merupakan tindakan yang dilakukan pemerintah maupun tidak dilakukan pemerintah.

Menurut Dunn (dalam elwan, 2011), analisis kebijakan adalah aktivitas intelektual dan praktis yang ditujukan untuk menciptakan, secara kritis menilai, dan mengkomunikasikan pengetahuan dan dalam proses kebijakan. Analisis kebijakan adalah disiplin ilmu sosial terapan yang menggunakan berbagai metode pengkajian multiple dalam konteks argumentasi dan debat politik untuk menciptakan, secara kritis menilai, dan mengkomunikasikan pengetahuan yang relevan tentang kebijakan.

Metode analisis kebijakan menurut Dunn (dalam elwan, 2011) menggabungkan lima prosedur umum yang lazim dipakai dalam pemecahkan masalah manusia, yaitu:

1) Definisi: menghasilkan informasi mengenai kondisi yang menimbulkan masalah kebijakan.

2) Prediksi: menyediakan informasi mengenai konsekuensi dimasa datang dari penerapan alternatif kebijakan, termasuk bila tidak dilakukan sesuatu.

3) Preskripsi/rekomendasi: menyediakan informasi mengenai nilai konsekuensi alternatif kebijakan dimasa mendatang.

4) Deskripsi/pemantauan: menghasilkan informasi mengenai konsekuensi sekarang dan masa lalu dari diterapkannya alternatif kebijakan.

5) Evaluasi: menghasilkan informasi mengenai kegunaan alternatif kebijakan dalam memecahkan masalah.

Kebijakan mengandung suatu unsur tindakan untuk mencapai tujuan dan umumnya tujuan tersebut ingin dicapai oleh seseorang, kelompok ataupun pemerintah.Kebijakan tentu mempunyai hambatan-hambatan tetapi harus mencari peluang-peluang untuk mewujudkan tujuan dan sasaran yang diinginkan. Hal tersebut berarti kebijakan tidak boleh 
Vol.2 No.2. May-July 2019. pp.84-98. Copyright@2019 Journal PUBLICUHO Faculty of Social and Political Sciences Halu Oleo University, Kendari, Southeast Sulawesi, Indonesia. e-ISSN: 2621-1351.Open Access at:

http://ojs.uho.ac.id/index.php/PUBLICUHO

Jounal publiuho is licensed under a Creative Commons Attribution 4.0 International License, which permits unrestricted use, distribution, and reproduction in any medium, provided the original work is properly cited.

bertentangan dengan nilai-nilai dan praktik-praktik sosial yang ada dalam masyarakat. Apabila kebijakan berisi nilai-nilai yang bertentangan dengan nilai-nilai yang hidup dalam masyarakat, maka kebijakan tersebut akan mendapat kendala ketika diimplementasikan. Sebaliknya, suatu kebijakan harus mampu mengakomodasikan nilai-nilai dan praktikpraktik yang hidup dan berkembang dalam masyarakat.

Analisis kebijakan publik adalah kajian ilmu terapan yang mempunyai tujuan memberikan rekomendasi kepada public policy maker dalam rangka memecahkan masalah-masalah publik.Di dalam analisis kebijakan terdapat informasi-informasi berkaitan dengan masalahmasalah kebijakan publik serta argumen-argumen tentang berbagai alternatif kebijakan, sebagai bahan pertimbangan atau masukan kepada pihak pembuat kebijakan.

Dalam arti luas, analisis kebijakan adalah satu bentuk penelitian terapan yang dilakukan untuk memperoleh pemahaman yang mendalam mengenai masalah-masalah sosial teknis dan untuk mencari solusi-solusi yang lebih baik.Karena berusaha menggunakan ilmu modern dan teknologi modern dalam menyelesaikan masalah-masalah masyarakat, analisis kebijakan mencari langkah-langkah yang mudah diamati, menyusun informasi dan bukti-bukti serta pengaruh-pengaruh yang diakibatkan oleh penerapan suatu kebijakan yang dilakukan untuk membantu para pembuat kebijakan didalam memilih tindakan yang paling menguntungkan. Operation riset, analisis sistem, sistem biaya dan manfaat dan analisis efektifitas biaya ada dalam kategori yang sama dan sering dipakai dalam studi analisis kebijakan. Namun analisis kebijakan memperhitungkan kesulitan-kesulitan politik dan organisasi yang berhubungan dengan keputusan publik dan implementasinya.

Analisis kebijakan publik tidak hanya pengamatan suatu kebijakan dengan melihat kedalam komponen-komponennya namun juga desain dan sintesis dari alternatif-alternatif baru.Kegiatan-kegiatan tersebut meliputi penelitian untuk menjelaskan atau memberikan pandangan atas isu atau masalah yang diantisipasi, hingga penelitian evaluasi dari suatu program keseluruhan.

Analisis kebijakan publik adalah kajian ilmu terapan yang mempunyai tujuan memberikan rekomendasi kepada public policy maker dalam rangka memecahkan masalah-masalah publik.Di dalam analisis kebijakan terdapat informasi-informasi berkaitan dengan masalahmasalah kebijakan publik serta argumen-argumen tentang berbagai alternatif kebijakan, sebagai bahan pertimbangan atau masukan kepada pihak pembuat kebijakan.

Dalam arti luas, analisis kebijakan adalah satu bentuk penelitian terapan yang dilakukan untuk memperoleh pemahaman yang mendalam mengenai masalah-masalah sosial teknis dan untuk mencari solusi-solusi yang lebih baik.Karena berusaha menggunakan ilmu modern dan teknologi modern dalam menyelesaikan masalah-masalah masyarakat, analisis kebijakan mencari langkah-langkah yang mudah diamati, menyusun informasi dan bukti-bukti serta pengaruh-pengaruh yang diakibatkan oleh penerapan suatu kebijakan yang dilakukan untuk membantu para pembuat kebijakan didalam memilih tindakan yang paling menguntungkan. Operation riset, analisis sistem, sistem biaya dan manfaat dan analisis efektifitas biaya ada dalam kategori yang sama dan sering dipakai dalam studi analisis kebijakan. Namun analisis kebijakan memperhitungkan kesulitan-kesulitan politik dan organisasi yang berhubungan dengan keputusan publik dan implementasinya.

Analisis kebijakan publik tidak hanya pengamatan suatu kebijakan dengan melihat kedalam komponen-komponennya namun juga desain dan sintesis dari alternatif-alternatif baru. Kegiatan-kegiatan tersebut meliputi penelitian untuk menjelaskan atau memberikan pandangan atas isu atau masalah yang diantisipasi, hingga penelitian evaluasi dari suatu program keseluruhan. (Dunn dalam elwan, 2011)

Secara umum, berikut tahap-tahap dalam proses pembuatan kebijakan menurut Dunn (Dunn dalam elwan, 2011) adalah sebagai berikut: 
Vol.2 No.2. May-July 2019. pp.84-98. Copyright@2019 Journal PUBLICUHO Faculty of Social and Political Sciences Halu Oleo University, Kendari, Southeast Sulawesi, Indonesia. e-ISSN: 2621-1351. Open Access at:

http://ojs.uho.ac.id/index.php/PUBLICUHO

Jounal publiuho is licensed under a Creative Commons Attribution 4.0 International License, which permits unrestricted use, distribution, and reproduction in any medium, provided the original work is properly cited.

1. Fase Penyusunan Agenda, dimana para pejabat yang dipilih dan diangkat menempatkan masalah pada agenda publik;

2. Fase Formulasi Kebijakan, para pejabat merumuskan alternatif kebijakan untuk mengatasi masalah;

3. Fase Adopsi Kebijakan, alternatif kebijakan yang diadopsi dengan dukungan mayoritas legislatif dan atau konsensus kelembagaan;

4. Fase Implementasi Kebijakan, kebijakan yang telah diambil dilaksanakan oleh unit-unit administrasi yang memobilisasi sumberdaya finansial dan manusia;

5. Fase Penilaian Kebijakan, disini unit-unit pemeriksaan dan akuntasi menilai apakah lembaga pembuat kebijakan dan pelaksana kebijakan telah memenuhi persyaratan pembuatan kebijakan dan pelaksanaan kebijakan yang telah ditetapkan.

\section{B. Konsep Pengembangan}

Wibowo, et al (1999) mengatakan bahwa pengembangan wilayah merupakan usaha mengembangkan dan meningkatkan hubungan saling ketergantungan dan interaksi antar system, manusia atau masyarakat, lingkungan hidup dan sumber daya alam.Penelitian yang dilakukan Ahmed dan Hossein (1990), menunjukan bahwa daerah yang infrastruktur transportasinya berkembang, memperoleh keuntunan yang signifikan dibanding dengan desa-desa yang infrastruktur transportasinya belum berkembang. Hasil penelitian yang dilakukan World Bank (1994) perkembangan pembangunan infrastruktur jalan telah meningkatkan aktivitas social masyarakat, yang kemudian meningkatkan aktivitas ekonomi, komunikasi, dan akhirnya dapat menciptakan berbagai lapangan kerja baru.

Menurut Adisasmita (2011), pengembangan wilayah di artikan sebagai upayah pembangunan pada suatu wilayah atau beberapa daerah untuk mencapai kesejahteraan masyarakat dengan memanfaatkan berbagai sumbar daya alam, sumber daya manusia, sumber daya kelembagaan, sumber daya teknologi dan prasarana fisik secara efektif, optimal dan berkelanjutan. Konsep pengembangan wilayah di Indonesia lahir dari suatu proses interaktif yang menggabungkan dasar-dasar pemahaman teoritis dengan pengalaman-pengalaman praktis sebagai bentuk penerapannya yang bersifat dinamis. Dengan kata lain, konsep pengembangan wilayah di Indonesia merupakan penggabungan dari berbagai teori dan model yang senantiasa berkembang yang telah diuji terapkan dan kemudian dirumuskan kembali menjadi suatu pendekatan yang disesuaikan dengan kondisi dan kebutuhan pembangunan di Indonesia.

Pembangunan infrastruktur merupakan salah satu factor pendukung pembangunan ekonomi suatu Negara, Bhattacharyay (2008) telah mengidentifikasi peran penting infrastruktur dalam pembangunan wilayah, yaitu sebagai factor dasar yang dapat mendorong perubahan ekonomi di berbagai sektor lokal maupun internasional. Terdapat beberapa manfaat infrastruktur terhadap perekonomian yaitu: (1) mengurangi biaya produksi (2) memperluas kesempatan kerja dan konsumsi karena terbukanya daerahdaerah yang terisolir, dan (3) menjaga stabilitas ekonomi makro melalui investasi pada infrastruktur yang dapat menyerap tenaga kerja dan meningkatkan daya beli konsumen. Suatu wilayah akan berkembang jika ada kegiatan perdagangan interinsuler dari wilayah tersebut ke wilayah lain sehingga terjadi peningkatan investasi pembangunan dan peningkatan kegiatan ekonomi serta perdagangan. Pendapatan yang di peroleh dari ekspor akan mengakibatkan perkembangan kegiatan penduduk setempat, perpindahan modal dan tenaga kerja, keuntungan eksternal dan perkembangan wilayah (damapolii, 2008).

Pengembangan infrastruktur adalah bagian integral dari pembangunan nasioanal.Infrastruktur merupakan roda penggerak pertumbuhan ekonomi.Kegiatan sektor 
Vol.2 No.2. May-July 2019. pp.84-98. Copyright@2019 Journal PUBLICUHO Faculty of Social and Political Sciences Halu Oleo University, Kendari, Southeast Sulawesi, Indonesia. e-ISSN: 2621-1351.Open Access at:

http://ojs.uho.ac.id/index.php/PUBLICUHO

Jounal publiuho is licensed under a Creative Commons Attribution 4.0 International License, which permits unrestricted use, distribution, and reproduction in any medium, provided the original work is properly cited.

transportasi merupakan tulang punggung pola distribusi baik barang maupun penumpang.Pendekatan pembangunan infrastruktur berbasis wilayah semakin penting untuk di perhatikan.Pengalaman menunjukan bahwa infrastruktur transportasi laut berperan penting untuk membuka isolasi wilayah, serta ketersediaan pengairan merupakan prasyarat kesuksesan pembangunan pertanian dan sekto-sektor lainnya.

\section{Konsep Infrastruktur Transportasi Laut}

Dalam rangka mewujudkan kesejahteraan, Indonesia memiliki Rancangan Program Jangka Panjang Nasional (RPJPN) tahun 2005 -- 2025 dengan sasaran "Terwujudnya Indonesia sebagai negara kepulauan yang mandiri, maju, kuat, dan berbasiskan kepentingan nasional". Mulai tahun 2017, dana yang dianggarkan untuk infrastruktur lebih tinggi dibanding dengan sektor-sektor lainnya. tercatat dalam APBN 2017 pemerintah memprioritaskan pembangunan infrastruktur dengan anggaran sebesar 387,3 Triliun rupiah, naik menjadi $123,4 \%$ per tahun 2017, hal ini mengindikasikan bahwasannya pemerintah mendukung penuh pembangunan infrastruktur di Indonesia. Dalam hal ini, kaitannya dengan infratruktur laut adalah adanya program pemerintah yang dinamakan tol laut.Tol laut adalah sebuah gagasan dengan memandang laut sebagai penghubung berbagai daerah yang ada di Indonesia.Program ini sudah berjalan sejak awal November 2015. Dengan adanya program tersebut sudah sewajaranya pemerintah akan membangun pelabuhan dan galangan kapal sebagai ujung tombak penggerak perekonomian antar pulau di Indonesia. Kondisinya Indonesia masih mengalami permasalahan dari segi penyebaran dan kuantitasnya.

Dalam Undang-Undang Nomor 27 Tahun 2007 tentang Pengelolaan Wilayah Pesisir dan Pulau-Pulau Kecil Pasal 5 meliputi :

a. Rencana Strategis Wilayah Pesisir dan Pulau-Pulau Kecil (RSWP-3-K)

b. Rencana Zonasi Wilayah Pesisir dan Pulau-Pulau Kecil (RZWP-3-K)

c. Rencana Pengelolaan Wilayah Pesisir dan Pulau-Pulau Kecil (RPWP-3-K)

d. Rencana Aksi Pengelolaan Wilayah Pesisir dan Pulau-Pulau Kecil (RAPWP-3-K)

Dalam muatan RSWP-3-K, berisikan arahan kebijakan dalam penyusunan RZWP-3-K, RPWP3-K, dan RAPWP-3-K dan Rencana yang memuat Arah Kebijakan Lintas Sektor untuk Kawasan perencanaan pembangunan melalui Penetapan Tujuan, Sasaran Dan Strategi Yang Luas Serta Target Pelaksanaan dengan indikator yang tepat untuk memantau Rencana Tingkat Nasional.

Sedangkan muatan dalam RZWP-3-K, berisikan Rencana yang menentukan Arah Penggunaan Sumber Daya tiap-tiap satuan perencanaan disertai dengan penetapan struktur dan pola ruang pada kawasan perencanaan yang Memuat Kegiatan Yang Boleh Dilakukan Dan Tidak Boleh Dilakukanserta kegiatan yang hanya dapat dilakukan setelah memperoleh izin dan arahan Pemanfaatan Sumber Daya di Wilayah Pesisir dan PulauPulau Kecil pemerintah Provinsi Dan Pemerintah Kab/Kota.

Dalam system transportasinasional dinyatakan bahwa jasa transportasi dilakukan secara efektif dan efisien yang dapat di lakukan melalui optimalisasi operasional sarana dan prasarana, baik intra maupun antar moda. Tatanan intra dan antar moda transportasi di arahkan agar terdapat keterpaduan dalam arti keselarasan, keserasian, dan keseimbangan dalam rangka memelihara saling berhubungan (interrelationship) dan saling ketergantungan (interdependency) antar moda transportasi, guna mendukung peaksanaan pembangunan di sektor-sektor ekonomi dan bidang pembangunan lain secara efektif dan efisien. Lebih spesifik di bidang transportasi laut, arah kebijakan sarana dan prasarana transportasi laut mengacu pada system transportasi nasional serta mempertimbangkan pengaruh lingkungan strategis yaitu (Nasution, 2008).

Kemudian, berdasarkan ketentuan undang-undang pelayaran (UURI No.17 tahun 2008) yang berlaku untuk semua kegiatan angkutan perairan, kepelabuhanan, keselamatan 
Vol.2 No.2. May-July 2019. pp.84-98. Copyright@2019 Journal PUBLICUHO Faculty of Social and Political Sciences Halu Oleo University, Kendari, Southeast Sulawesi, Indonesia. e-ISSN: 2621-1351. Open Access at:

http://ojs.uho.ac.id/index.php/PUBLICUHO

Jounal publiuho is licensed under a Creative Commons Attribution 4.0 International License, which permits unrestricted use, distribution, and reproduction in any medium, provided the original work is properly cited.

dan keamanan pelayaran, serta perlindungan lingkungan maritime di wilayah Indonesia. Pelayaran di selenggarakan berdasarkan; a) asas manfaat, b) asas usaha bersama dan kekelvargaan, c) asas persaingan sehat, d) asas adil dan merata tanpa diskriminasi, e) asas keseimbangan, keserasian, dan keselarasan, f) asas kepentingan umum, g) asas keterpaduan, h) asas tegaknya hukum, i) asas kemandirian, j) asas berwawasan lingkungan hidup, k) asas kedaulatan Negara, dan I) asas kebangsaan.

\section{Angkutan di Perairan untuk Daerah Masih Tertinggal dan/atau wilayah terpencil}

Angkutan di perairan untuk daerah masih tertinggal dan/atau wilayah terpencil wajib di laksanakan oleh pemerintah daerah.Angkutan di perairan sebagai mana dimaksud dilaksanakan dengan pelayaran-perintis dan penugasan.Pelayaran-perintis sebagaimana dimaksud dilaksanakan dengan biaya yang disediakan oleh pemerintah daerah .penugasan sebagai mana dimaksud diberikan kepada perusahaan angkutan laut nasional dengan mendapatkan mendapatkan kompensasi dari pmerintah daerah sebesar selisih antara biaya produksi dan tarif yang di tetapkan pemerintah daerah sebagai kewajiban pelayanan public. Pelayaran-perintis dan penugasan dilaksanakan secara terpadu dengan sektor lain berdasarkan pendekatan pembangunan wilayah.

\section{Tujuan Pengembangan Infrastruktur Transportasi Laut}

Dalam pengembangan bidang ekonomi, pelabuhan memiliki beberapa fungsi yang sama - sama dapat meningkatkan ekonomi suatu negara. Pelabuhan bukan hanya digunakan sebagai tempat merapat bagi sebuah kapal melainkan juga dapat berfungsi untuk tempat penyimpanan stok barang, seperti contohnya sebagai tempat penyimpanan cadangan minyak dan peti kemas (container), karena biasanya selain sebagai prasarana transportasi manusia pelabuhan juga kerap menjadi prasarana transportasi untuk barang barang. Menurut Bintarto R.(1968), dalam segi kepentingan suatu daerah pelabuhan memiliki arti ekonomis yaitu karena pelabuhan mempunyai fungsi sebagai tempat ekspor impor dan kegiatan ekonomi lainnya yang saling berhubungan sebab akibat. Dengan adanya kegiatan di pelabuhan, maka keuntungan secara ekonomi yang langsung dapat dirasakan adalah terbukanya banyak lapangan kerja bagi masyarakat sekitar, karena dalam segala bidang kegiatan di pelabuhan tenaga kerja manusia akan sangat dibutuhkan seperti contohnya tenaga kerja sebagai kuli (untuk mengangkat barang barang), pengatur lalu lintas pelabuhan (terutama pengatur lalu lintas kendaraan yang akan masuk ke kapal), dan petugas kebersihan pelabuhan.

Tinjauan mengenai pengaruh pelabuhan terhadap perkembangan ekonomi suatu negara dijelaskan juga oleh Abdul Haris(2011) infrastruktur berpengaruh penting bagi peningkatan kualitas hidup dan kesejahteraan manusia, antara lain peningkatan nilai konsumsi, peningkatan produktivitas tenaga kerja, serta peningkatan kemakmuran masyarakat sekitar. Dengan adanya pelabuhan maka barang - barang dagang banyak masuk ke sebuah negara, hal ini juga bertujuan untuk memenuhi keinginan masyarakat untuk mengkonsumsi barang tersebut.Mengingat sekarang ini merupakan jaman pasar global, maka tingkat keinginan untuk mengkonsumsi barang - barang yang sedang menjadi trend-center pun meningkat, walaupun barang tersebut bukan berasal dari negaranya. Yang sering kali terjadi juga adalah setelah barang impor datang dan sudah diperjual belikan di suatu negara, masyarakat negara itu baru sadar bahwa barang yang sedang di perjual belikan tersebut adalah barang yang sedang menjadi trend-center, oleh karena itu tidak heran jika tiba - tiba permintaan masyarakat suatu negara terhadap suatu barang tiba - tiba sangat tinggi, dan hal itu secara tidak langsung meningkatkan nilai konsumsi masyarakat suatu negara.

Penelitian idris dan susanti (2016), pengembangan infrastruktur pelabuhan dalam mendukung pembangunan berkelanjutan, jurnal penelitian ilmiah Engineering Vol. 5 No. 1 
Vol.2 No.2. May-July 2019. pp.84-98. Copyright@2019 Journal PUBLICUHO Faculty of Social and Political Sciences Halu Oleo University, Kendari, Southeast Sulawesi, Indonesia. e-ISSN: 2621-1351.Open Access at:

http://ojs.uho.ac.id/index.php/PUBLICUHO

Jounal publiuho is licensed under a Creative Commons Attribution 4.0 International License, which permits unrestricted use, distribution, and reproduction in any medium, provided the original work is properly cited.

januari 2006, ISSN: 2087-9334. Hasil penelitiannya menggungkapkan bahwa operasional pelayanan pelabuhan Bungkutoko kendari menunjukan bahwa rata-rata kapal bekerja di tambatan (ET) yaitu 36.48 jam dan rata-rata lamanya satu kapal berada dipelabuhan (BT) yaitu 85.41 jam, pemanfaatan dermaga (bor) kurang baik yaitu 56.50\%. pemanfaatan gudang/lapangan penumpukan relative rendah karena menggunakan system truk losing. Kebutuhan dermaga petikemas di pelabuhan Bungkutoko memerlukan pembangunan 1 unit dermaga, pelayanan angkutan petikemas dan multi guna sangat lambat dibangding kebutuhan sehingga pelayanan waktu kapal dan kelancaran komoditi belum begitu memuaskan masyarakat. Fasilitas dermaga dan lapangan penumpukan pada umumnya kritis untuk menghadapi pertumbuhan lalu lintas angkutan laut untuk periode 5 tahun mendatang. Strategi pengembangan yaitu perluasan pembangunan infrasruktur, dengan kebijakan meningkatkan investasi pemerintah di bidang infrastruktur, meningkatkan dan perluasan kapasitas infrastruktur dan peningkatan akses jaringan jalan wilayah pelabuhan.

\section{Kerangka Pikir}

Berdasarkan kajian teoritis yang dikemukakan dapat dinyatakan bahwa begitu pentingnya peran infrastruktur transportasi terutama dalam hal ini infrastruktur transportasi laut.Sehingga diperlukan perumusan kebijakan yang din lakukan pemerintah Kabupaten Muna Barat dalam hal ini Dinas Perhubungan Kabupaten Muna Barat dalam pengembangan infrastruktur transportasi laut yakni pada Pelabuhan Rakyat di Desa Pajala dengan melakukan investasi infrastruktur, pembangnan infrasturktur pelabuhan, dan perluasan kapasitasyang dapat memberikan dampak dalam pertumbuhan ekonomi, penciptaan lapangan kerja, dan pembangunan ekonomi nasional dan regional. Dengan adanya kebijakan pengembangan infrastruktur transportasi laut yang di lakukan oleh Pemerintah Kabupaten Muna Barat di harapkan dapat memberikan dampak positif dalam bidang ekonomi maupu bidang lainnya pada Kabupaten Muna Barat.

\section{Gambar. 1 kerangka pikir penelitian analisis kebijakan}

\section{Kebijakan pengembangan pelabuhan}

1. Investasi infrastruktur

2. Pembangunan infarstruktur pelabuhan

3. Perluasan kapasitas pelabuhan (Idris dan Susanti, 2016)

\section{Manfaat pengembangan infrastruktur transportasi}

1. Pertumbuhan ekonomi

2. Penciptaan lapangan kerja

3. Pembangunan ekonomi nasional dan regional

(Abdul Haris, 2011)

\section{METODE PENELITIAN}

Penelitian ini di lakukan di Dinas Perhubungan Kabupaten Muna Barat. Dengan pertimbangan bahwa instansi teknis Dinas Perhubungan berkaitan erat dengan proses pengambilan kebijakan dan pengembangan infrastruktur transportasi laut. Selain itu objek penelitian ini yaitu institusi pemerintah yang berkaitan langsung dengan pengambilan kebijakan publik tentang pengembangan infrastruktur transportasi laut khususnya peningkatan fasilitas sarana prasarana kepelabuhanan dan fasilitas pendukungnya.

\section{A. Tipe dan Dasar Penelitian}

Tipe penelitian ini adalah penelitian Kualitatif dengan tipe penelitian deskriptif analitik, yaitu penelitian yang di arahkan untuk menggambarkan fakta dan argument yang tepat.Penelitian yang di lakukan nantinya di harapkan nantinya dapat memberikan 
Vol.2 No.2. May-July 2019. pp.84-98. Copyright@2019 Journal PUBLICUHO Faculty of Social and Political Sciences Halu Oleo University, Kendari, Southeast Sulawesi, Indonesia. e-ISSN: 2621-1351. Open Access at:

http://ojs.uho.ac.id/index.php/PUBLICUHO

Jounal publiuho is licensed under a Creative Commons Attribution 4.0 International License, which permits unrestricted use, distribution, and reproduction in any medium, provided the original work is properly cited.

gambaran mengenai kebijakan dalam pengembangan infrastruktur transportasi laut di Kabupaten Muna Barat.

\section{B. Informan Penlitian}

Informan menurut Moleong (2006:132) adalah orang yang di manfaatkan untuk memperoleh informasi tentang situasi dan kondisi latar penelitian serta berkaitan dengan variable penelitian.Informan penelitian ini di tentukan dengan teknik purposive yaitu memilih informan menurut kriteria tertentu yang telah ditetapkan yang sesuai dengan topik penelitian, maka di tetapkan informan penelitian berjumlah 3 orang yang terdiri dari Kepala Dinas, Sekretaris, dan Kepala bidang pengembangan dan keselamatan.

\section{Sumber Data}

a. Data primer bersumber dari komunikasi langsung dengan para informan berupa pendapat atau opinitentang kebijakan yang ada dan langkah yang di tempuh dalam menyikapi permasalahan yang ada.

b. Data sekunder bersumber dari buku, literature-literatur, serta informasi tertulis lainnya yang berkenaan dengan masalah yang di teliti. Selain itu terdapat situs-situs atau website yang di akses untuk memperoleh data yang lebih akurat.

\section{Teknik Pengumpulan Data}

Adapun teknik pengumpulan data yang di rencanakan untuk di gunakan di lapangan adalah sebagai berikut:

1. Wawancara adalah percakapan dengan maksud tertentu, yang di lakukan oleh pewawancara yang mengajukan pertanyaan dan yang diwawancarai yang memberikan jawaban. Penelitian ini akan mengambil data primer dari wawancara yang di lakukan terhadap sejumlah informan yang di anggap paham dan mengetahui dengan jelas masalah yang akan di teliti.

2. Dokumentasi; dalam penelitian ini penulis melakukan pengumpulan dokumen yang berhubungan dengan kegiatan wawancara bersama narasumber yang berada pada Dinas Perhubungan Kabupaten Muna Barat.

\section{E. Teknik Analisis Data}

Teknik analisis data yang di lakukan dalam penelitian ini adalah analisis deskriptif kualitatif.Data yang telah di peroleh di lokasi penelitian baik yang bersifat data primer maupun data sekunder kemudian di olah dan ditabulasi berdasakan sifat dan jenisnya selanjutnya di interprestasi secara deskriptif untuk menjawab rumusan maslah. Langkahlangkah kegiatan analisis di lakukan menurut Miles dan Huberman (1994: 19) sebagai berikut:

(1) Pengumpulan data; (2) Reduksi data; data yang terkumpul di pilih dan di kelompokan berdasarkan data yang mirip atau sama. Kemudian data ini di organisasikan untuk mendapatkan data sebagai bahan penyajian data; (3) Pengecekan keabsahan data; adalah upayah untuk memilah dan memilih data yang paling objektif dan valid sebagai data penelitian dengan pertimbangan sebgai berikut: a) hanya memasukan data yang benar-benar objektif; b) hanya memasukan data yang autentik; dan c) membedakan antara data informasi dengan pesan pribadi responden; (4) Penyajian data; (5) Penarikan kesimpulan atau verifikasi.

\section{PEMBAHASAN}

\section{Kebijakan Pemerintah Kabupaten Muna Barat dalam Pengembangan Infrastruktur Transportasi Laut}

Kebijakan pengembangan transportasi laut yang menjadi materi pembahasan dalam penelitian ini adalah materi program kegiatan pengembangan pelabuhan dan dermaga yang menjadi program kegiatan Bidang Pengembangan dan Keselamatan Dinas Perhubungan Kabupaten Muna Barat. Program kegiatan pengembangan tersebut terdiri dari kegiatan perencanaan dan kegiatan pelaksanaan. 
Vol.2 No.2. May-July 2019. pp.84-98. Copyright@2019 Journal PUBLICUHO Faculty of Social and Political Sciences Halu Oleo University, Kendari, Southeast Sulawesi, Indonesia. e-ISSN: 2621-1351.Open Access at:

http://ojs.uho.ac.id/index.php/PUBLICUHO

Jounal publiuho is licensed under a Creative Commons Attribution 4.0 International License, which permits unrestricted use, distribution, and reproduction in any medium, provided the original work is properly cited.

Adapun perencanaan pengembangan infrastruktur transportasi laut Dinas Perhubungan Kabupaten Muna Barat yaitu sebagai berikut :

a. Dermaga rakyat Latawe; akses jangkauan yang melayani angkutan penumpang dari Kota Kendari - Muna Barat atau sebaliknya dengan kapal cepat/spit

b. Dermaga Rakyat Pajala; akses jangkauan melayani angkutan penumpang dari Bombana - Muna Barat atau sebaliknya dengan kapal cepat/spit;

c. Dermaga Rakyat di pulau-pulau kawasan Selat Tiworo meliputi dermaga rakyat pulau Maginti, Pulau Balu, Pulau Gala, Pulau Santigi, Pulau Mandike, Pulau Tasipi, Pulau Katela, Pulau Bangko, dan dermaga Wisata Pualu Indo.

\section{Rencana Pengembangan}

Pada tahun 2018 rencana kegiatan pengembangan yang dilakukan oleh Bidang Pengembangan dan Keselamatan Dinas Perhubungan Kabupaten Muna Barat pada beberapa pelabuhan yang masuk dalam RIPN, sebagaimana penjelasan Kepala Bidang Pengembangan dan Keselamatan Dinas Pehubungan Kabupaten Muna Barat, adalah sebagai berikut,

1) Kegiatan/program Studi Kelayakan; Kegiatan studi kelayakan dilakukan dalam rangka melakukan penilaian atau evaluasi secara teknis dan ilmiah berdasarkan kondisi factual kawasan pembangunan, denhan tujuan untuk menetapakan status layak atau tidaknya sebuah kawasan pelabuhan dikembangkan sesuai dengan kebutuhan dan peruntukanya.

2) Kegiatan/program Pembuatan Rencana Induk Pelabuhan (Master Plan); Pembuatan Rencana Induk Pelabuhan (RIP) atau master plan pelabuhan dimaksudkan agar pelaksanaan kegiatan pengembangan sebuah pelabuhan nantinya telah memiliki arah dan tujuan yang jelas karena telah ditetapkan kedudukan dan status seluruh komponen bangunan dan pendukung dari sebuah pelabuhan.Master plan ini juga memuat arah kebijakan pengembangan pelabuhan untuk 20 tahun kedepan dengan tujuan agar perubahan dan perkembangan penduduk dan kawasan sekitar pelabuhan dapat terakomodir dengan master plan pelabuhan yang cukup panjang waktunya.

3) Pembuatan Detail Enginering Desain (DED); Konsep DED adala sebuah hasil pertimbangan teknis tetang tata letak dan pola bangunan pelabuhan, khususnya Dermaga Yang akan dibangun, karena DED adalah hasil analisis teknik terhadap rencana pembangunan sebuah bangunan pelabuhan, sehingga konsep ini sangat menentukan model dan struktur bangunan pelabuhan, sekaligus menentukan besaran biaya pembangunan sebuah pelabuhan.

4) Pembuatan Kajian Lingkungan

Sebagaimana Peraturan Menteri Lingkungan Hidup No. 09 tahun 2011 tentang kajian linggkungan hidup strategis, yang menekankan perlunya dibuat kajian terhadap sebuah rencana pembangunan yang bersifat sektoral maupun kewilayahan, maka pengembangan sebuah kawasan pelabuhan dan dermaga membutuhkan dokumen kajian lingkungan hidup.

Berdasarkan uraian diatas maka pada dokumen kegiatan perencanaan pengembangan pelabuhan tahun 2017 diketahui bahwa beberapa pelabuhan telah melakukan seluruh komponen kegiatan diatas adan sebagian lagi belum dilakukan, sebagai mana termuat dalam tabel berikut.

Tabel 1. Rencana Pengembangan Pelabuhan yang masuk dalam RIPN Tahun 2018

\begin{tabular}{llllll}
\hline \multirow{2}{*}{ No. } & Nama Pelabuhan & \multicolumn{4}{l}{ Kegiatan Perencanaan } \\
\cline { 3 - 6 } & & FS & RIP & DED & KJL \\
\hline $\mathbf{1}$ & Pelabuhan Rakyat Latawe & $\checkmark$ & $\checkmark$ & $\checkmark$ & $\checkmark$ \\
\hline $\mathbf{2}$ & Pelabuhan Rakyat Pajala & $\checkmark$ & $\checkmark$ & $\checkmark$ & $\checkmark$ \\
\hline $\mathbf{3}$ & Pelabuhan Rakyat Tanjung Pinang & $\checkmark$ & $\checkmark$ & & \\
\hline Jumlah & $\mathbf{3}$ & $\mathbf{3}$ & $\mathbf{2}$ & $\mathbf{2}$ \\
\hline
\end{tabular}

Sumber: Dinas Perhubungan Muna Barat 2018

|Journal Publicuho-Vol 2. No.2-2019| 
Vol.2 No.2. May-July 2019. pp.84-98. Copyright@2019 Journal PUBLICUHO Faculty of Social and Political Sciences Halu Oleo University, Kendari, Southeast Sulawesi, Indonesia. e-ISSN: 2621-1351. Open Access at:

http://ojs.uho.ac.id/index.php/PUBLICUHO

Jounal publiuho is licensed under a Creative Commons Attribution 4.0 International License, which permits unrestricted use, distribution, and reproduction in any medium, provided the original work is properly cited.

Berdasarkan uraian data di atas maka dapat diketahui bahwa program kegiatan rencana pengembangan pelabuhan yang masuk dalam RIPN pada tahun 2017, adalah sebanyak 10 (sepuluh) kegiatan yang terdiri dari Feasibility Study (studi kelayakan) pelabuhan sebanyak 3 kegiatan, pembuatan Rencana Induk Pelabuhan (Master Plan) pelabuhan sebanyak 3 kegiatan, pembuatan Detail Enginering Desain (DED) Pelabuhan sebanyak 2 kegiatan, dan pembuatan Kajian Lingkungan (KJL) Pelabuhan sebanyak 2 kegiatan. Dengan demikian, dapat di nyatakan bahwa kebijakan pengembangan infrastruktur transportasi laut yang dilakukan oleh pihak Dinas Perhubungan Kabupaten Muna Barat yang merupakan bagian dari program nasional telah berjalan sesuai dengan arahan kebijakan pengembangan transportasi laut nasional.

\section{A. Analisis kebijakan pemerintah dalam Pengembangan Pelabuhan 1. Investasi Infrastruktur}

Efektifitas investasi infrastruktur transportasi untuk meningkatkan perekonomian dan memberikan manfaat bagi masyarakat tergantung kepada pemanfaatan sarana transportasi tersebut oleh produsen maupun konsumen serta sektor-sektor unggulan, sehingga mampu memberikan stimulus perekonomian seperti yang diharapkan. Penyediaan infrastruktur transportasi yang baik seperti halnya jalan, jembatan, pelabuhan dan lainnya diyakini dapat memicu limpahan (spill-over) investasi dari wilayah sekitarnya ke wilayah Muna Barat.

Pengembangan dengan mempertimbangkan sektor ekonomi misalkan dengan melihat kepada sektor-sektor unggulan yang berkembang di Muna Barat. Sedangkan dimensi kewilayahan diperhatikan agar pengembangan infrastruktur transportasi dapat menjangkau wilayah atau daerah terpencil (desa) yang potensial secara ekonomi untuk mempercepat pertumbuhan ekonomi di wilayah tersebut, menyerap tenaga kerja serta memperbaiki pemerataan pendapatan. Secara garis besar, stimulus berupa investasi infrastruktur transportasi diharapkan menjadi pemicu peningkatan perekonomian daerah maupun nasional.

Berdasarkan hasil wawancara tersebut, maka dapat disimpulkan bahwa dalam hal pemenuhan kebutuhan untuk investasi dalam pengembangan infrastruktur transportasi laut Dinas Perhubungan Kabupaten Muna Barat telah melakukan kerjasama dengan salah satu pihak swasta untuk menginvestasikan sebuah kapal yang beroperasi pada rute pajala-kasipute.Ini merupakan kebijakan penting yang diambil oleh pihak pemerintah daerah khususnya Dinas Perhubungan Kabupaten Muna Barat dalam meningkatkan efektivitas pembangunan dengan beroperasinya kapal tersebut. Selain itu juga telah ada permohonan terhadap ASDP untuk memberikan sebuah kapal Ferry yang akan di operasikan dengan rute Tondasi-Kasipute.

\section{Pembangunan Infrastruktur Pelabuhan}

Pada pelabuhan Rakyat Pajala sangat dibutuhkan pembangunan dan pengembangan infrastruktur yang lebih memadai sehingga bias menambah daya Tarik dari para pengguna transportasi laut mengingat Pelabuhan Rakyat Pajala terhubung langsung dengan pelabuhan yang ada di Kasipute sehingga jalur transportasi lebih terbuka.

Berdasarkan hasil wawancara dari informan, dapat disimpulkan bahwa Dinas Perhubungan Kabupaten Muna Barat telah Mengambil Beberapa kebijakan dalam pengembangan infrastruktur transportasi yang dapat di lihat dari pengembangan Pelabuhan Rakyat Pajala dan Pelabuhan Rakyat Latawe serta dibangunnya beberapa dermaga di pulau-pualau kecil yang ada di Muna Barat. Sebagai kabupaten baru maka kebijakan pengembangan infrastruktur transportasi laut yang dilakukan oleh Dinas Perhubungan Kabupaten Muna Barat bisa dikatakan efektif yang diharapkan bisa menunjang perkembangan daerah agar bisa menambah daya saing daerah dengan Kabupaten-kabupaten lain yang ada di Sulawesi Tenggara. 
Vol.2 No.2. May-July 2019. pp.84-98. Copyright@2019 Journal PUBLICUHO Faculty of Social and Political Sciences Halu Oleo University, Kendari, Southeast Sulawesi, Indonesia. e-ISSN: 2621-1351.Open Access at:

http://ojs.uho.ac.id/index.php/PUBLICUHO

Jounal publiuho is licensed under a Creative Commons Attribution 4.0 International License, which permits unrestricted use, distribution, and reproduction in any medium, provided the original work is properly cited.

\section{Perluasan Kapasitas Pelabuhan}

Keberadaan pelabuhan merupakan hal yang sangat penting mengingat Kabupaten Muna Barat merupakan wilayah kepulauan yang memiliki laut yang luas dan terhubung langsung dengan beberapa kabupaten dan provinsi di Indonesia.

Wilayah Muna Barat memiliki berapa pulau kecil yang berpenghuni maka sangat di butuhkan kebijakan perluasan kapasitas pelabuhan sehingga bisa di manfaatkan oleh para pelaku ojek perahu untuk tempat berlabu dan menunggu penumpang sehingga pelabuhan tidak hanya di manfaatkan untuk akses penghubung antar kabupaten tetapi juga sebagai akses penghubung antar pulau di Muna Barat itu sendiri.

Sebagai mana yang diungkapkan oleh Kepala Bidang Pengembangan Dinas Perhubungan Kabupaten Muna Barat yang diperoleh melalui wawancara bahwa:

"Perluasan kapasitas pelabuhan memang sangat penting dilakukan untuk itu kami telah mengambil kebijakan dengan sasaran perluasan kapasitas Pelabuhan Rakyat Pajala dimana kami telah menambah bentang panjang dermaga sepanjang 50 meter hal inilah yang menjadi salah satu pertimbagan para investor untuk memberikan investasi berupa kapal karena dengan adanya penambahan panjang dermaga maka tingkat kedalaman dasarlaut tempat kapal berlabu juga semakin dalam sehingga tidak ada kendala apa bila kapal akan berlabu (wawancara, 14 Januari 2019).

Berdasarkan hasil wawancara diatas maka dapat disimpulkan bahwa kebijakan penambahan kapasitas pelabuhan yang dilakukan oleh Dinas Pehubungan Muna Barat telah berhasil menarik perhatian Para investor untuk memberikan investasi. Terbukti dengan beroperasinya kapal pada Pelabuhan Rakyat Pajala dengan rute Pajala-Kasipute yang kemudian kapal cepat yang akan berpoerasi pada Pelabuhan Rakyat Latawe yang masih menunggu selesainya pengerjaan penambahan bentang panjang pelabuhan tersebut. Hal ini menunjukan kesungguhan Dinas Perhubungan Kabupaten Muna Barat dalam menggenjot membangunan dan pengembangan pelabuhan yang ada di Kabupaten Muna Barat untuk menarik minat para investor sera memanfaatkan letak strategis laut Muna Barat untuk mendorong membangunan ekonomi daerah.

\section{B. Manfaat Pengembangan Infrastruktur Pelabuhan}

1. Pertumbuhan Ekonomi

Berdasarkan hasil wawancara di atas maka pengembangan pelabuhan sangat di harapkan agar dapat menunjang pertumbuhan ekonomi masyarakat maupun daerah karena dengan adanya pelabuhan tersebut maka akan terjadi kegiatan pelayaran yang menghubungkan antara Muna Barat dengan beberapa Kabupaten yang ada di Sulawesi Tenggara bahkan Kabupaten atau Provinsi lain diluar Sulawesi Tenggara yang bisa merangsang kelancaran perdagangan antar kota sekaligus bisa mengoptimalkan perputaran ekonomi dalam daerah yang bisa membangun ekonomi daerah sendiri.

\section{Penciptaan Lapangan Kerja}

Dengan adanya kegiatan di pelabuhan, maka keuntungan secara ekonomi yang langsung dapat di rasakan adalah terbukanya lapangan kerja bagi masyarakat sekitar, karena dalam segala bidang kegiatan di pelabuhan tenaga keja manusia akan sangat di butuhkan contohnya seperti tenaga kerja sebagai kuli, pengatur lalu lintas terutama pengatur lalu lintas kendaraan yang akan masuk ke kapal, dan petugas kebersihan pelabuhan.

Dengan adanya pengembangan infrastruktur pelabuhan secara tidak langsung akan menciptakan lapangan kerja baru bagi masyarakat sekitar untuk menciptakan segala potensi baik itu berdagang atau berjualan di sekitar pelabuhan, menjadi kuli angkut barang penumpang maupun sebagai petugas kebersihan pelabuhan. Dalam segala hal 
Vol.2 No.2. May-July 2019. pp.84-98. Copyright@2019 Journal PUBLICUHO Faculty of Social and Political Sciences Halu Oleo University, Kendari, Southeast Sulawesi, Indonesia. e-ISSN: 2621-1351. Open Access at:

http://ojs.uho.ac.id/index.php/PUBLICUHO

Jounal publiuho is licensed under a Creative Commons Attribution 4.0 International License, which permits unrestricted use, distribution, and reproduction in any medium, provided the original work is properly cited.

kegiatan kepelabuhanan sangat di butuhkan tenaga kerja manusia dan itu berarti memberi peluang kepada masyarakat dalam hal pekerjaan.

Berdasarkan hasil wawancara dapat disimpulkan bahwa dengan adanya pembangunan dan pengembangan pelabuhan memberikan dampak positif terhadap penciptaan lapangan kerja bagi masyarakat sekitar pelabuhandimana dengan adanya pelabuhan maka akan membuka kesempatan bagi masyarakat baik itu bisa bekerja sebagai kuli angkat barang dan juga sebagai petugas kebersihan pelabuhan. Masyarakat juga bisa membuka usaha sebagai pedagang kecil disekitar pelabuhan. Hal ini juga akan dirasakan para tenaga kerja honorer yang ada pada Dinas Perhubungan Kabupaten Muna Barat dengan adanya pembagian tugas sehingga memiliki tugas masing-masing yang biasanya tidak memiliki tugas dan hanya datang di kantor Dinas Perhubungan.

\section{Pembangunan Ekonomi Nasional dan Regional}

Dalam pembangunan ekonomi, pembangunan infrastruktur menjadi aspek salah satu aspek penting.Tidak bisa dipungkiri bahwa laju pertumbuhan ekonomi Negara maupun daerah tidak lepas dari pengaruh infrastruktur yang ada dalam Negara maupun daerah itu sendiri. Pertumbuhan ekonomi ini pada akhirnya akan perpengaruh pada kesejahteraan masyarakat.

Begitu pula dengan pembangunan infrastruktur pelabuhan. Pembangunan pelabuhan sangat tidak kalah penting dan diperlukan sebagai alat penghubung suatu daerah dengan daerah lain terlebih mengingat Indonesia merupaka Negara kepulauan seperti halnya Kabupaten Muna Barat yang merupakan wilayah kepulauan. Degan adanya pelabuhan maka akses akan mudah dijangkau yang akan mempengaruhi unsur strategis suatu daerah dan dengan mudahnya akses akan mempengaruhi banyaknya pihak swasta yang mau berinvestasi. Dengan banyaknya pihak swasta yang mau berinvestasi tersebut akan mempengaruhi pada pertumbuhan ekonomi yang cukup pesat.

Dampak pengembangan pelabuhan terhadap pembangunan ekonomi suatu daerah maupun Negara memang jelas adanya. Fakta empiris menunjukan bahwa perkembangan kapasitas pelabuhan suatu wilayah berjalan seiring dengan adanya perkembangan output ekonomi. Ini berarti secara langsung, pelabuhan berdampak pada peningkatan kegiatan ekonomi secara positif.

Sebagai mana yang diungkapkan oleh Sekretaris Dinas Perhubungan Kabupaten Muna Barat yang kami peroleh melalau hasil wawancara mengatakan bahwa,

"Pelabuhan-pelabuhan yang ada merupakan asset pemerintah pusat dalam hal ini kementrian KPDT yang telah diserahkan kepada pemerintah Kabupaten Muna Barat yang sekarang menjadi perhatian Pemerintah Derah untuk dipelihara dan dikembangkan menjadi pelabuhan besar yang melayani pengguna jasa dengan berbagai rute yakni Pajala-Bombana pulang pergi serta akan dikembangkan

menjadi pelabuhan nusantara kemudian pelabuhan Rakyat Latawe yang saat ini masih dalam proses pengembangan akan melayani pengguna jasa dengan rute Latawe-Kendari. Dengan adanya pelabuhan ini maka akan mempercepat pembangunan ekonomi daerah karena arus transportasi lancar, hasil komoditi sector pertanian, perikanan, dan peternakan bisa di pasarkan di luar daerah dan begitu pula sebaliknya. (wawancara, 21 Januari 2019)".

Pernyataan informan tersebut menunjukan bahwa kebijakan pengembangan infrastruktur pelabuhan sangat penting dilakukan karena pelabuhan merupakan asset berharga bagi daerah maupun Negara dalam menjalankan perputaran roda perekonomian masyarakat maupun daerah yang berujung pada pembangunan ekonomi daerah maupun Negara itu sendiri. Maka dapat disimpulkan bahwa keberadaan pelabuhan memliki peran yang sangat penting untuk menunjang laju pertumbuhan ekonomi daerah Muna Barat terlebih lagi Muna Barat adalah Kabupaten baru sehingga pembangunan pelabuhan semacam ini harus sangat diperhatikan demi kemajuan ekonomi daerah. 


\section{KESIMPULAN}

Berdasarkan hasil analisis dan pembahasan yang sebagai mana diuraikan sebelumnya, maka dapat disajikan kesimpulan yaitu sebagai berikut :

1. Berdasarkan hasil analisis mengenai kebijakan pengembangan pelabuhan oleh Dinas Perhubungan Kabupaten Muna Barat, disimpulkan bahwa kebijakan yang telah diambil dan dilaksanakan oleh Dinas Perhubungan Kabupaten Muna Barat dalam pengembangan pelabuhan sudah cukup baik dan optimal dengan adanya pembangunan dan pengembangan serta pengoperasian kembali Pelabuhan Rakyat Pajala serta adanya investasi beberapa kapal baik dari pihak swasta maupun ASDP.

2. Manfaat pengembangan infrastruktur transportasi laut berdampak positif perekonomi masyarakat sekitar karena akan membuka jalur transportasi baru yang memudahkan masyarakat dan akan memperlancar jalur perdagangan karena nilainya yang cukup ekonomis sekaligus juga akan membuka lapangan kerja yang bisa dimanfaatkan oleh masyarakat sekitar yang akan berdampak pada peningkatan taraf hidup masyarakat. Selain itu juga pengembangan pelabuhan merupakan salah satu asset dalam pembangunan ekonomi daerah.

\section{SARAN}

Berdasarkan kesimpulan yang telah dijabarkan, penulis menyarankan agar kebijakan yang dibuat dalam pengembangan pelabuhan pada Kabupaten Muna Barat harus brujung pada Implementasi yang maksimal agar bisa memperoleh hasil yang bisa bermanfaat bagi masyarakat maupun untuk daerah itu sendiri. Selain itu sumber daya aparatur dapat dibenahi kembali guna tercapainya keseimbangan kualitas sumber daya manusia yang ada, kemudian dalam pelayanan publik harus di tingkatkan dan kedisiplinana pegawai harus ditingkatkan serta diberi pengawasan yang ketat, dalam pelaksanaan kebijakan harus dilakukan secara maksimal agar hasil yang diperoleh sesuai dengan yang direncanakan dan memuaskan serta mendukung dalam pembangunan daerah itu sendiri. 
Vol.2 No.2. May-July 2019. pp.84-98. Copyright@2019 Journal PUBLICUHO Faculty of Social and Political Sciences Halu Oleo University, Kendari, Southeast Sulawesi, Indonesia. e-ISSN: 2621-1351. Open Access at:

http://ojs.uho.ac.id/index.php/PUBLICUHO

Jounal publiuho is licensed under a Creative Commons Attribution 4.0 International License, which permits
unrestricted use, distribution, and reproduction in any medium, provided the original work is properly cited.

\section{DAFTAR PUSTAKA}

Adisasmita, Sakti Adji. 2011. Perncanaan Pembangunan Transportasi, Edisi Pertama. Graha Ilmu, Yogyakarta.

Anderson, James E. 1979. Public Policy Making. Boston: Houghton Mifflin.

Bhattacharyay, B. N. 2008. Estimating Deman for Infrastructur In Energy, Transport, Telecomunication, Water and Sanitation in Asia and Pasific. Working Pper.Asia Development Bank Institute (ABDI) Research Policy No. 248.

Bintarto, R. 1968. Beberapa Aspek Geografi. Yogyakarta: Karya.

Damapolii, Deddy Wahyudi. 2008. Peran Pelabuhan Labuan Uki Terhadap Pengembangan Wlayah Kabupaten Bolaang Mongondow, Master Thesis Jurusan Pengembangan Wilayah dan Kota, Universitas Diponegoro, Semarang Gurning.

Ho, m.w. dan Ho, K.H. 2006. "Risk Management in Large Physical Infrastructurelnvestment: The Context of Seaport Ifrastructure Developmentadan Investment", Maritime Economi and Logistics, Palgrave Macmillan, 2006 Vol.8, hlm 140-168.

Idris A. Putra dan Susanti Djalante.2016.Pengembangan Infrastruktur Pelabuhan Dalam Mendukung Pembangunan Berkelanjutan, Jurnal IImiah Media Engineering Vol. 6 No. 1 Tahun 2016.Januari 2016 (433-4) ISSN: 2087-9334.Diunduh tanggal 17 Oktober 2018.

La Ode Muhammad Elwan, S. (2011). IMPLEMENTASI PERDA KOTA KENDARI NO. 15 TAHUN 2003 TENTANG PARTISIPASI MASYARAKAT DALAM PERUMUSAN KEBIJAKAN DAERAH PADA PENYUSUNAN ANGGARAN PENDAPATAN BELANJA DAERAH TAHUN 2010. Universitas Gadjah Mada.

Miles, M.B. \& Huberman, A.M. 1994.Qualitative Data Analysis. London: Sage Publishers.

Moleong, L.J. 2006.Metodologi penelitian Kualitatif, PT. Remaja Rosdakarya. Bandung.

Nasution, M. N. 2008. Manajemen Transportasi. Raja Grafindo, Jakarta.

Peraturan Menteri Lingkungan Hidup No. 09 tahun 2011 tentang kajian linggkungan hidup strategis

Undang-undang Republik Indonesia Nomor. 17 Tahun 2008 tentang Pelayaran, Tambahan Lembaran Negara Nomor.17452 Tahun 2008. Sekretariat Negara Republik Indonesia, Jakarta.

Wibowo, et al. 1999.Konsep, Teori dan Landasan Analisis Wilayah.Bayumedia. Malang

World Bank. 1994. World Development Report: Infrastruktur For Development. Oxford University Press, New York. 